\title{
Mangrove habitat partitioning by Ucides cordatus (Ucididae): effects of the degree of tidal flooding and tree-species composition during its life cycle
}

\author{
A. C. Wunderlich • M. A. A. Pinheiro
}

Received: 15 March 2012/Revised: 17 July 2012/ Accepted: 23 July 2012/Published online: 17 August 2012

(C) Springer-Verlag and AWI 2012

\begin{abstract}
Environmental factors strongly affect mangrove crabs, and some factors modulate population structure and habitat partitioning during the crabs' life cycle. However, the effect of these environmental factors on habitat selection by mangrove crabs is still unknown. We evaluated habitat selection by the mangrove crab Ucides cordatus in mangrove forests with different degrees of predominance of Rhizophora mangle, Laguncularia racemosa or Avicennia schaueriana, two tidal flooding levels (less- and more-flooded), and two biological periods (breeding and non-breeding seasons). Sampling was conducted in four mangrove forests with different influences of these biotic and abiotic parameters. We used the data for sex ratio to explain environmental partitioning by this species. Females predominated in $R$. mangle mangroves, independently of the biological period (breeding or nonbreeding seasons), and males predominated only in the less-flooded $L$. racemosa mangroves. The flooding level affected the sex ratio of $U$. cordatus, with a predominance of males in less-flooded mangroves, independently of the biological period; and a gender balance in the more-flooded mangroves only during the breeding season. Outside the breeding season, the largest specimens were recorded in the
\end{abstract}

Communicated by L. Gutow.

A. C. Wunderlich

Instituto de Biociências de Botucatu (IBB),

Univ Estadual Paulista (UNESP), Distrito de Rubião Jr.,

s/n, Botucatu, SP 18618-970, Brazil

M. A. A. Pinheiro ( $\square)$

Grupo de Pesquisa em Biologia de Crustáceos (CRUSTA),

Campus Experimental do Litoral Paulista (CLP),

Univ Estadual Paulista (UNESP), Praça Infante Dom Henrique,

s/n., Parque Bitaru, São Vicente, SP 11330-900, Brazil

e-mail: pinheiro@clp.unesp.br
R. mangle mangroves, but in the breeding season, the largest crabs were recorded in the $L$. racemosa mangroves with a higher level of flooding. These results suggest that tree-species composition and tidal flooding level can have a significant effect on the habitat partitioning of sexes and sizes of the mangrove crab $U$. cordatus both during and outside the breeding season.

Keywords Flood H Habitat selection - Neotropical mangroves $\cdot$ Sex ratio $\cdot$ Tidal effects - Ucides cordatus

\section{Introduction}

Environmental effects on the population structure and sex ratio in mangrove crabs have been little studied (deRivera 2003), particularly in species of the genera Uca (Frith and Brunenmeister 1980; deRivera 2003; Mokhtari et al. 2008) and Ucides (Monteiro and Filho 2004; Diele et al. 2005; Piou et al. 2009). However, the influences of certain abiotic and biotic parameters on the population biology of these brachyurans are comparatively well known, especially the effects of temperature (Kelemec 1979), salinity (Frusher et al. 1994), tides (Reinsel 2004; Turra et al. 2005), species composition of mangrove trees (Icely and Jones 1978), and sediment granulometry (Mouton and Felder 1996; Morrisey et al. 1999; Ribeiro et al. 2005).

According to Icely and Jones (1978), Piou et al. (2009), and Sandrini-Neto and Lana (2011), the spatial distribution and population structure of mangrove crabs can change as a function of one or more parameters, especially the species composition of the mangroves (Schories et al. 2003; Koch et al. 2005; Nordhaus and Wolff 2007), degree of flooding (Whitehouse et al. 2001; Reinsel 2004), and texture and organic matter content of the sediment (Frusher et al. 1994), 
Fig. 1 Location of each mangrove forest, with a predominance of Laguncularia racemosa $\left(L h_{1-3}\right.$ high mangroves; $L l_{1-3}$ low mangroves), Avicennia schaueriana $\left(\mathrm{A}_{1-3}\right)$, or Rhizophora mangle $\left(\mathrm{R}_{1-3}\right)$, at Iguape Municipality, State of São Paulo, southeast Brazil (Source Ikonos IV ${ }^{\circledR}$ Satellite image provided by EngesSat ${ }^{(\circledR)}$ )

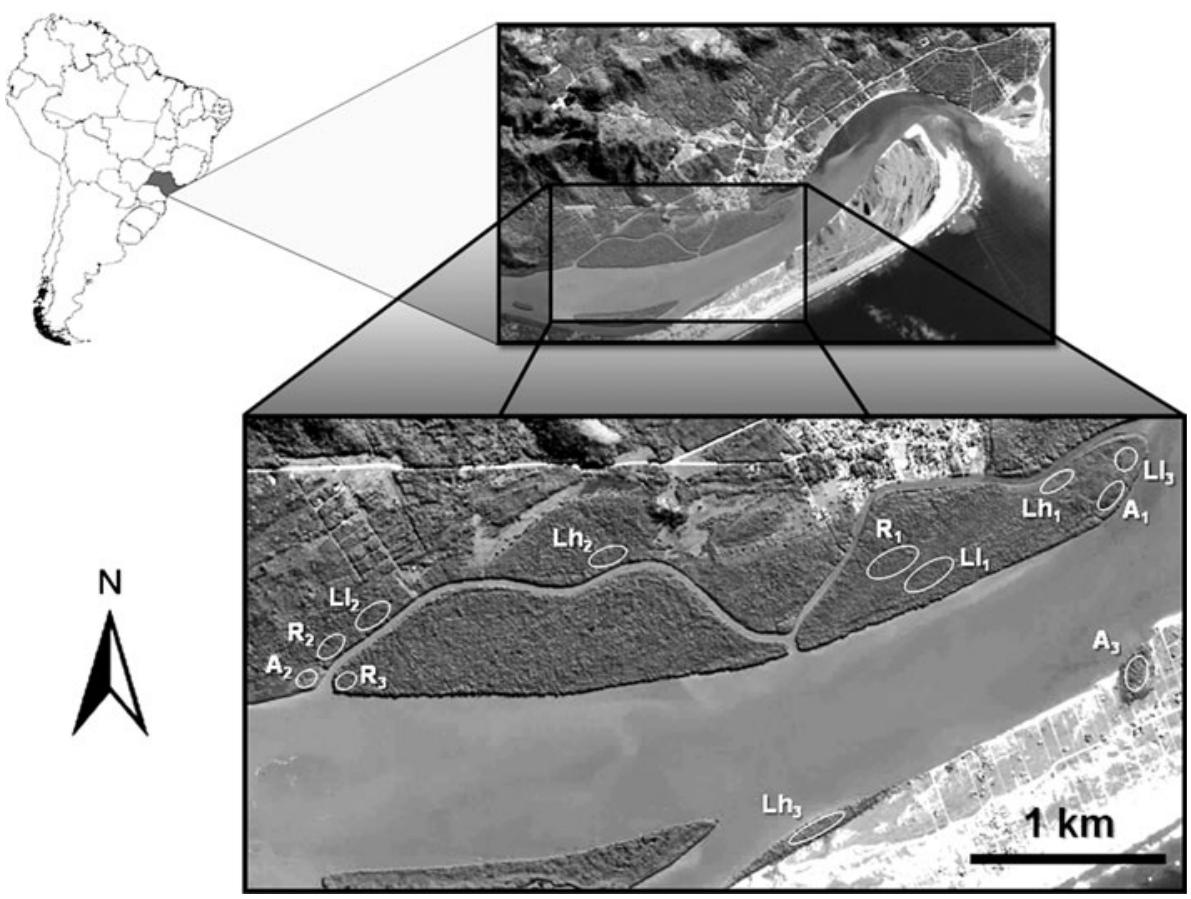

leaf litter; see Christofoletti 2005), in the same Neotropical mangrove areas studied here.

\section{Methods}

Study area

The study was carried out in mangroves of the CananéiaIguape-Peruíbe Environmental Protection Area (APA/CIP), between $24^{\circ} 21^{\prime} \mathrm{S}-46^{\circ} 59^{\prime \prime} \mathrm{W}$ and $25^{\circ} 18^{\prime \prime} \mathrm{S}-48^{\circ} 06^{\prime \prime} \mathrm{W}$, on the south coast of the state of São Paulo, Brazil. The mangroves are located in Iguape Municipality, next to Barra de Icapara $\left(24^{\circ} 41^{\prime} \mathrm{S}\right.$ and $\left.47^{\circ} 28^{\prime} \mathrm{W}\right)$, between Comprida Island and the continent; this extensive mangrove-bay complex is known as the "Mar de Dentro" (Fig. 1). The APA/CIP is about $75 \mathrm{~km}$ long (Mendonça 2007), comprising 2 mouths-'Icapara' (North) and 'Cananéia' (South). Miyao et al. (1986) recorded salinities from 18 to 30, and Cunha-Lignon et al. (2009) characterized this area as: (1) mean annual rainfall $2,300 \mathrm{~mm}$ (with most precipitation between January and March); (2) mean annual temperature $23.8^{\circ} \mathrm{C}$ (lowest in July and highest in February, with $19.8-27.8^{\circ} \mathrm{C}$ ); (3) micro-tidal regime with semi-diurnal and diurnal inequalities.

Sampling methods

During June 2007 through November 2008, crabs were collected in 12 mangrove forests $\left( \pm 3,600 \mathrm{~m}^{2}\right.$ each), which were characterized by a predominance of different tree 

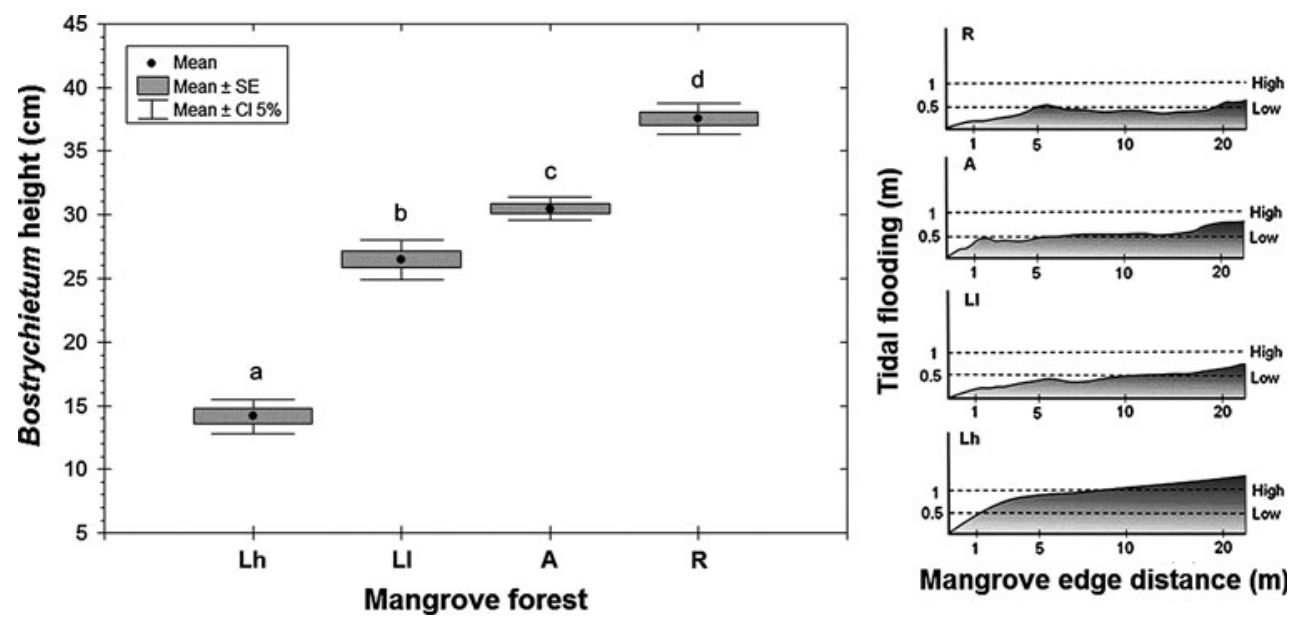

Fig. 2 Box and whisker plots of Bostrychietum height (left) to characterize the flooding level and its topographic profile with tidal flooding levels (right), in each mangrove forest according to the predominance of Laguncularia racemosa ( $L h$ high mangrove; $L l$ low mangrove), Avicennia schaueriana (A), or Rhizophora mangle (R), at
Iguape Municipality, State of São Paulo, southeast Brazil, where $S E$ standard error, $C I 5 \%$ confidence interval at $5 \%=1.96 * \mathrm{SE}$; means indicated with a different letter were statistically heterogeneous $(P<0.01)$

Data analysis

Laguncularia racemosa $(\mathrm{L})$, and three each of Avicennia schaueriana (A) and Rhizophora mangle (R) (Fig. 1). To analyze the effect of tidal flooding level on the sex ratio, we used six areas of L. racemosa (three replicates for each flooding level), which were categorized as: (1) high mangroves (Lh), with lower level or rare frequency of flooding during some spring tides; and (2) low mangroves (Ll), with higher levels or frequency of flooding during neap and spring tides (see Fig. 2). The height of the Bostrychietum on the mangrove stems and roots was used to characterize the flooding level of each area (Fig. 2). The Bostrychietum is a group algae, mainly members of Rhodophycea-Bostrychia Mont., Caloglossa (Harv.) G. Martens and Catenella Grev., according to Pedroche et al. (1995) — that occur as epiphytes on basal stems of mangrove trees (Post 1936; Feller and Sitnik 1996), and is a useful indicator of flooding level in these ecosystems (Alves 2011).

Crabs were caught by "braceamento", a manual method where the fisherman inserts his arm into the burrow and catches the crab by its dorsal carapace (Nordi et al. 2009). This method is permitted by the Brazilian law that protects this species (Brasil 2011). We used the same crab-catcher in all the mangrove areas to avoid a bias in the data. In each mangrove forest $\left( \pm 10,800 \mathrm{~m}^{2}\right)$, a minimum of 200 specimens of $U$. cordatus were randomly collected per biological period, sexed by inspection of the abdomen shape and number of pleopods (Pinheiro and Fiscarelli 2001), measured (CW, carapace width) with a precision vernier caliper $(0.05 \mathrm{~mm})$, and released in the same place where they were caught.
The influence of the mangrove tree-species composition on the $U$. cordatus population sex ratio was evaluated by excluding the effect of flooding level and comparing data among mangrove forests with similar levels and frequencies of flooding. To evaluate the effect on the biological period of this species, we compared the data obtained for the same mangrove forests in two biological periods (JuneJuly 2007 and October-November 2008), which correspond to the non-breeding (April-September) and breeding (October-March) seasons for this species (see Pinheiro and Fiscarelli 2009).

The sex ratio as a function of size $(\mathrm{CW})$ was evaluated according to Wenner (1972), by analyzing the distribution of the specimens in size classes $(5 \mathrm{~mm})$, establishing the proportion of males in each class (minimum of 10 specimens/class), and verifying the classification by the trend of the empirical points. The difference in sex ratio was evaluated by $\chi^{2}$ test (Wilson and Hardy 2002; Zar 2010), with a comparison between mangrove forests of the same tree species (using replicates), forests with different tree composition ( $\mathrm{Lh}, \mathrm{Ll}, \mathrm{A}$, or $\mathrm{R}$ predominance), biological period (non-breeding and breeding seasons), and level of flooding (high and low mangroves). The data for size (carapace width) for each sex in different mangrove forests were submitted to ANOVA and their means compared by Tukey's test (5 \%) (Sokal and Rohlf 1995).

The normality of data was assessed by KolmogorovSmirnov test (Zar 2010). All statistical analyses and graphs were performed in R software (R Development Core Team 2009). 
Table 1 Sex ratio (male/female) of Ucides cordatus in each mangrove forest with different predominant tree species (L, Laguncularia racemosa; A, Avicennia schaueriana; and R, Rhizophora mangle), flooding level ( $L h$ less-flooded; $L l$ more-flooded), and biological period ( $N B$ non-breeding season; $B$ breeding season), in Iguape Municipality, State of São Paulo, southeast Brazil

\begin{tabular}{|c|c|c|c|c|c|c|}
\hline \multirow[t]{2}{*}{ Biological periods/mangrove forests } & \multicolumn{2}{|l|}{ Males } & \multicolumn{2}{|c|}{ Females } & \multirow[t]{2}{*}{ Sex ratio (M:F) } & \multirow[t]{2}{*}{$\chi^{2}$} \\
\hline & $N$ & $\%$ & $N$ & $\%$ & & \\
\hline \multicolumn{7}{|l|}{ Non-breeding (NB) } \\
\hline Lh & 191 & 77.6 & 55 & 22.4 & $1: 0.29$ & $75.18 * * *$ \\
\hline $\mathrm{Ll}$ & 132 & 58.7 & 93 & 41.3 & $1: 0.70$ & $6.76^{*}$ \\
\hline A & 92 & 40.5 & 135 & 59.5 & $1: 1.47$ & $8.14 *$ \\
\hline $\mathrm{R}$ & 95 & 42.2 & 130 & 57.7 & $1: 1.37$ & $5.44 *$ \\
\hline \multicolumn{7}{|l|}{ Breeding $(B)$} \\
\hline Lh & 206 & 66.9 & 102 & 33.1 & $1: 0.49$ & $35.11 * * *$ \\
\hline $\mathrm{Ll}$ & 152 & 48.3 & 163 & 51.7 & $1: 1.07$ & $0.38^{\mathrm{ns}}$ \\
\hline A & 140 & 55.8 & 111 & 44.2 & $1: 0.80$ & $3.35^{\mathrm{ns}}$ \\
\hline $\mathrm{R}$ & 98 & 39.7 & 149 & 60.3 & $1: 1.52$ & $10.53 *$ \\
\hline \multicolumn{7}{|l|}{ Total $(N B+B)$} \\
\hline Lh & 397 & 71.7 & 157 & 28.3 & $1: 0.39$ & $193.97 * * *$ \\
\hline $\mathrm{Ll}$ & 284 & 52.6 & 256 & 47.4 & $1: 0.90$ & $1.45^{\mathrm{ns}}$ \\
\hline A & 232 & 48.5 & 246 & 51.5 & $1: 1.06$ & $0.41^{\mathrm{ns}}$ \\
\hline $\mathrm{R}$ & 193 & 40.9 & 279 & 59.1 & $1: 1.44$ & $15.66^{* * *}$ \\
\hline Total & 1.106 & 54.1 & 938 & 45.9 & $1: 0.85$ & $13.81 * *$ \\
\hline
\end{tabular}

$\chi^{2}$ test of goodness of fit testing the null hypothesis of equal proportions between sexes for each area; $* P<0.05 ; * * P<0.01$; *** $P<0.001$; ${ }^{n s} P>0.05$

\section{Results}

We collected a total of 2,044 crabs (1,106 males and 938 females) in the 12 mangrove areas. The overall sex ratio was 1:0.85 (males/females), which differed statistically from the $1: 1$ expected for most crustaceans $\left(\chi^{2}=13.81\right.$; $P=0.002$ ) (Table 1). The mangroves differed in the topography (based on the Bostrychietum height), with four distinct flooding levels $(F=313.82 ; P<0.001)$ following the hierarchical sequence $\mathrm{Lh}<\mathrm{Ll}<\mathrm{A}<\mathrm{R}$ (Fig. 2).

The overall sex ratio of $U$. cordatus changed with the biological period $\left(\chi^{2}=14.69 ; P<0.001\right)$. During the nonbreeding season $(\mathrm{NB})$, one sex predominated $(P<0.05)$, with the proportions differing among the forests with different dominating mangrove species; that is, males in L. racemosa areas and females in A. schaueriana and $R$. mangle forests (Table 1). This changed in the breeding season (B), when the sex ratio was similar in the intermediate-flooded areas $\mathrm{Ll}(P=0.22)$ and A $(P=0.52)$, although the previous pattern was maintained in Lh and R, with males and females dominating, respectively. This same pattern was confirmed when the data were grouped (see Table 1).

The mean size of the specimens (CW) also differed between the mangrove types during the non-breeding season $(F=44.3 ; P<0.0001)$ (Table 2; Fig. 3$)$, with the largest specimens associated with Rhizophora and
Avicennia mangroves (more-flooded areas), compared to the less-flooded L. racemosa mangroves ( $\mathrm{Lh}$ and $\mathrm{Ll}$ ). Size differences were also recorded in the breeding season $(F=65.5 ; \quad P<0.0001)$, when the largest specimens occurred in the more-flooded $L$. racemosa areas (Ll), and the smallest ones were associated with $\mathrm{Lh}$ (females) or $\mathrm{Lh}$ and $\mathrm{R}$ mangrove areas (males). During the breeding season, the mean size decreased in both sexes only in the Rhizophora mangroves, and increased in more-flooded areas of Laguncularia (Ll) (Fig. 3).

Hence, the sex ratio of $U$. cordatus differed according to flooding level (Fig. 4), with a lower frequency of mature females $(\mathrm{CW}>43 \mathrm{~mm})$ in less-flooded mangroves $(\mathrm{Lh})$, and males over $45 \mathrm{~mm}$ predominating. An inverse pattern occurred in the more-flooded mangroves (Ll), where females predominated in nearly all size classes, except for $\mathrm{CW}>65 \mathrm{~mm}$, in which males predominated.

In most of the mangrove forests (Lh, A, and R), the sex ratio as a function of size showed a similar trend between biological periods, despite the differences related to flooding level (Fig. 5). These areas contrasted with the more-flooded Laguncularia forest (Ll), where a high proportion of females occurred during the breeding season. In the $\mathrm{Lh}$ forest, males (CW $>45 \mathrm{~mm}$ ) dominated in both biological periods.

The population structure of each sex changed somewhat as a function of the biological period (Fig. 6). There was an 
Table 2 Biometry of Ucides cordatus in each mangrove forest with different predominant tree species (L, Laguncularia racemosa; A, Avicennia schaueriana; and R, Rhizophora mangle), flooding level
( $L h$ less-flooded; $L l$ more-flooded), and biological period ( $N B$ nonbreeding season; $B$ breeding season), in Iguape Municipality, State of São Paulo, southeast Brazil

\begin{tabular}{|c|c|c|c|c|c|c|}
\hline \multirow[t]{2}{*}{ Site } & \multirow[t]{2}{*}{ Sex } & \multirow[t]{2}{*}{$n$} & \multicolumn{4}{|c|}{ Carapace width (mm) } \\
\hline & & & Min & Max & Mean $\pm \mathrm{SE}^{*}$ & $\mathrm{CV}(\%)$ \\
\hline \multicolumn{7}{|c|}{ Non-breeding (NB) } \\
\hline \multirow[t]{2}{*}{ Lh } & M & 191 & 37.5 & 74.0 & $52.4 \pm 0.6 \mathrm{~b}$ & 16.4 \\
\hline & $\mathrm{F}$ & 55 & 24.7 & 70.0 & $45.9 \pm 1.1 \mathrm{a}$ & 17.7 \\
\hline \multirow[t]{2}{*}{$\mathrm{Ll}$} & M & 132 & 30.1 & 84.5 & $51.6 \pm 0.8 \mathrm{~b}$ & 17.6 \\
\hline & $\mathrm{F}$ & 93 & 30.2 & 72.1 & $47.1 \pm 0.8 \mathrm{a}$ & 16.8 \\
\hline \multirow[t]{2}{*}{ A } & M & 92 & 30.8 & 81.1 & $58.3 \pm 1.0 \mathrm{~cd}$ & 17.0 \\
\hline & $\mathrm{F}$ & 135 & 38.8 & 71.7 & $55.7 \pm 0.6 \mathrm{c}$ & 13.5 \\
\hline \multirow[t]{2}{*}{$\mathrm{R}$} & M & 95 & 31.3 & 83.2 & $63.1 \pm 1.0 \mathrm{de}$ & 15.2 \\
\hline & $\mathrm{F}$ & 130 & 41.7 & 72.9 & $58.4 \pm 0.5 \mathrm{c}$ & 10.4 \\
\hline \multicolumn{7}{|c|}{ Breeding (B) } \\
\hline \multirow[t]{2}{*}{ Lh } & M & 206 & 20.3 & 77.9 & $55.2 \pm 0.7 \mathrm{~b}$ & 18.7 \\
\hline & $\mathrm{F}$ & 102 & 30.1 & 65.6 & $46.7 \pm 0.7 \mathrm{a}$ & 15.6 \\
\hline \multirow[t]{2}{*}{$\mathrm{Ll}$} & M & 152 & 44.6 & 84.3 & $68.3 \pm 0.6 \mathrm{e}$ & 10.1 \\
\hline & $\mathrm{F}$ & 163 & 38.9 & 77.4 & $59.6 \pm 0.5 \mathrm{~d}$ & 11.2 \\
\hline \multirow[t]{2}{*}{ A } & M & 140 & 32.5 & 81.4 & $58.8 \pm 0.8 \mathrm{~cd}$ & 16.8 \\
\hline & $\mathrm{F}$ & 110 & 31.9 & 78.2 & $55.2 \pm 0.8 \mathrm{bc}$ & 15.2 \\
\hline \multirow[t]{2}{*}{$\mathrm{R}$} & M & 97 & 32.0 & 81.0 & $55.5 \pm 1.1 \mathrm{bc}$ & 20.0 \\
\hline & $\mathrm{F}$ & 149 & 35.2 & 73.0 & $54.1 \pm 0.6 \mathrm{~b}$ & 13.5 \\
\hline
\end{tabular}

$S E$ standard error, $C V$ coefficient of variation

* Means followed by a same letter are not significantly different $(P>0.05)$

increase in abundance of mature females ( $\mathrm{CW}>40 \mathrm{~mm}$ ) in $\mathrm{Lh}$ and $\mathrm{Ll}$ forests during the breeding season, while most females were immature $(\mathrm{CW}<45 \mathrm{~mm})$ during nonbreeding season. In mangrove forests $\mathrm{A}$ and $\mathrm{R}$, the abundance of females remained in equilibrium (independent of the biological period), with most females being mature individuals $(\mathrm{CW}>45 \mathrm{~mm})$. The abundance of large males $(\mathrm{CW}>65 \mathrm{~mm})$ increased slightly in the breeding season.

\section{Discussion}

We rejected the hypothesis of an equal ratio between the sexes in different mangrove forests and confirmed the alternative hypothesis, where the sexes and ages showed differences in occupation of these mangroves, with juvenile males mainly found in less-flooded L. racemosa forests and adult females in more-flooded ones ( $L$. racemosa low, A. schaueriana, and $R$. mangle). Our results suggest that habitat selection of $U$. cordatus is strongly affected by the interplay between the type of mangrove forests and the tidal flooding level. We found that females occurred mainly in mangrove forests with the highest flooding level. According to a previous study of the same areas (Christofoletti 2005), these mangroves are characterized by greater availability of litter, richness in nutrients ( $\mathrm{N}$ and $\mathrm{P}$ ), and a low concentration of polyphenols. In general, female crustaceans require more high-energy food items during gonadal maturation (Sastry 1983), with a significant feeding reduction when they are ovigerous (as confirmed for $U$. cordatus by Christofoletti 2005), due to their cryptic behavior. Besides, when the sex ratio is male-biased, the movement of males increases, to avoid male-male competition for females (Hazlett et al. 2005), causing changes in the sex ratio in some places. Juveniles of $U$. cordatus were recorded in higher densities in less-flooded L. racemosa forests (Hattori 2006), avoiding sites with adult males, because of intense competition for burrows and territories (Nordhaus et al. 2009). However, Diele and Simith (2007) suggested that $U$. cordatus megalopae settle in areas populated by conspecific crabs and/or muddy habitats, and generally cohabit in their burrows. This suggests that intraspecific competition occurs only after the pubertal molt, when morphological and hormonal changes lead to different reproductive behaviors and searching for preferred habitats, explaining the differential population structure observed in this study. Piou et al. (2009) mentioned differences in the spatial patterns according to developmental stage (juvenile and adult) 
Fig. 3 Box and whisker plots of carapace width (CW, in $\mathrm{mm}$ ) of Ucides cordatus in each mangrove forest, with a predominance of Laguncularia racemosa (Lh high mangroves; Ll low mangroves), Avicennia schaueriana (A), or R. mangle (R) by sex and biological period (breeding and non-breeding seasons), where $S E$ standard error, CI $5 \%$ confidence interval at $5 \%=1.96 * \mathrm{SE}$; means indicated with a different letter were statistically heterogeneous $(P<0.01)$

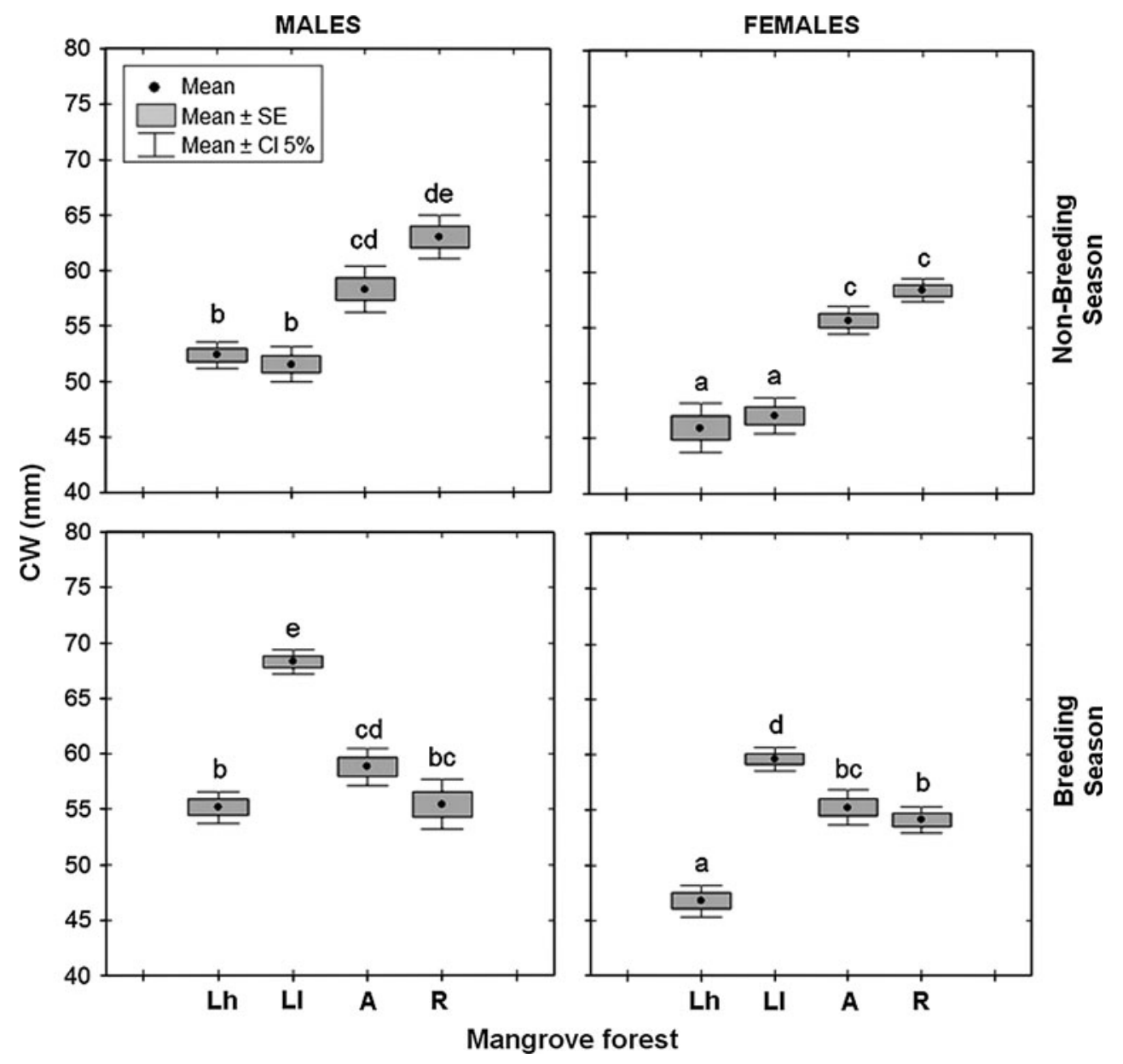

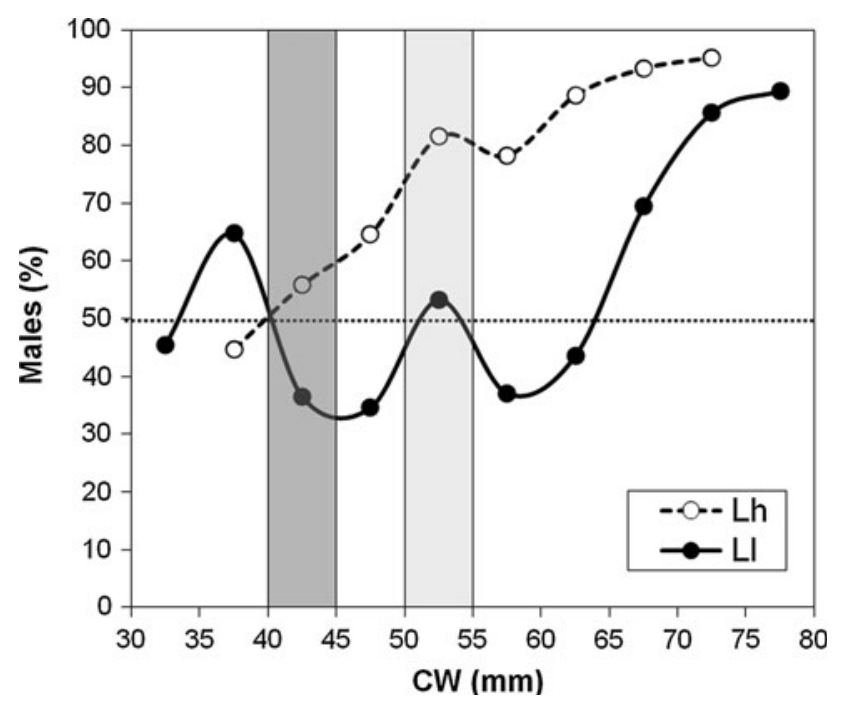

Fig. 4 Percentage of Ucides cordatus males by size classes $(\mathrm{CW}$ carapace width in millimeters) in two mangrove forests of the same treespecies composition (Laguncularia racemosa), but different flooding levels ( $L h$ high mangrove, with less-flooded level; and $L l$ low mangrove, with more-flooded level). Bars indicate size intervals, where size at onset of maturity occurs for females (dark gray) and males (light gray), according to Pinheiro and FiscarelIi (2001) of $U$. cordatus, attributed to exclusion of juvenile crabs due to the presence of adults. These authors explained this differential pattern in Neotropical mangroves by the influence of spatial distribution and preferred habitats on a regional scale; however, Sandrini-Neto and Lana (2011) established that a complex mosaic of patches exists on the small scale, as examined in this study.

Reviewing data obtained by Hattori (2006) in the same mangrove forests confirmed a greater abundance of juveniles in less-flooded $L$. racemosa forests, a balanced sex ratio in A. schaueriana and more-flooded L. racemosa forests, and a greater abundance of females in the R. mangle forests. Christofoletti (2005) carried out a quali-quantitative and nutritional evaluation of the litter, also in these same mangrove forests, and the differences in litter amount and quality explained the observed variations and differences in the population density and structure of the crabs. In general, larger-sized crabs are found in mangrove forests of $R$. mangle and A. schaueriana (Pinheiro et al. 2005; Hattori 2006), possibly because their leaves have higher nutritional value ( $\mathrm{N}$ and $\mathrm{P}$ ) and lower polyphenol concentration compared to L. racemosa leaves (Christofoletti 2005). Leaves of 


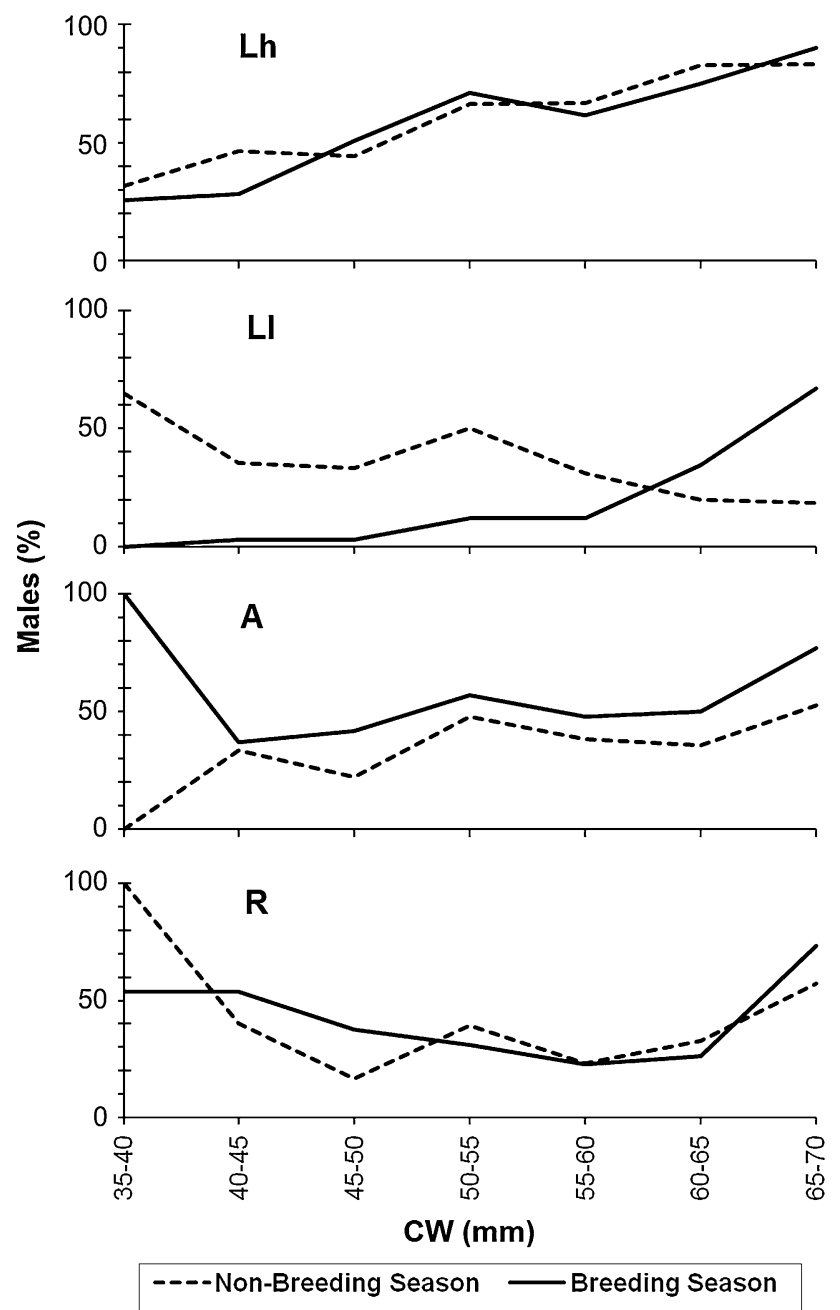

Fig. 5 Comparison of the percentage of Ucides cordatus males by size classes ( $C W$ carapace width in millimeters) in each mangrove forest (Lh Laguncularia racemosa high mangrove; Ll Laguncularia racemosa low mangrove; A, Avicennia schaueriana; R, Rhizophora mangle) as a function of the biological period (breeding and nonbreeding season)

L. racemosa in the study areas had a total polyphenol concentration approximately 10 times higher than those of R. mangle and A. schaueriana (Christofoletti 2005), which would have a negative influence on the growth/fattening of this crab, as observed for other crabs (Conde et al. 1995; Erickson et al. 2004) and arthropods (Reese et al. 1982; Fleck and Layne 1990; Hai and Yakupitiyage 2005). These phenolic compounds (polyphenols and tannin) can disrupt digestion and form complexes that resist digestion by this species (Rhoades and Cates 1976; Lacerda et al. 1986). Linton and Greenaway (2007) mentioned that leaves with high tannin content are not easily digested by crabs, confirming their anti-herbivory property (Godoy et al. 1997; Kandil et al. 2004); this explains the preference of some sesarmid crabs for mangrove leaves with lower concentrations of this alkaloid (Micheli 1993; Guerrero-Ocampo
2002). Data obtained by Nordhaus and Wolff (2007) suggest that the capacity of $U$. cordatus to digest leaves is not hampered by tannins, but also indicate that this species prefers $R$. mangle over Avicennia germinans leaves, due to a higher nitrogen content and lower $\mathrm{C} / \mathrm{N}$ ratio and tannin content. High tannin concentration may also decrease the availability of total leaf $\mathrm{N}$ content (Lacerda et al. 1986). Nordhaus et al. (2006) assumed that crabs fed more on propagules of $R$. mangle, which have a higher nutritive value than leaf litter; however, this was not confirmed by Christofoletti (2005), who reported a higher prevalence of leaves than propagules in stomach contents of $U$. cordatus.

In any event, the nutritional preference for leaves of certain tree species can markedly influence reproduction, particularly in females, as previously mentioned. On the other hand, the topographic heterogeneity of the mangrove, in particular the flooding level, leads to different local abundance patterns in crustacean populations (Rossi and Chapman 2003; Koch et al. 2005), as well as in the zonation patterns of the mangroves (Alongi and Sasekumar 1992). Different patterns of distribution in the size of mature specimens $(\mathrm{CW}>60 \mathrm{~mm})$ and density of $U$. cordatus were mentioned by Hattori (2006) and Schmidt (2006), as a function of tidal flooding in mangroves, reflecting the composition/vegetation structure and availability of leaves for feeding. However, based on a certain critical flooding level (not established in our study), the density would decline as a function of the longer exposure time during low tides, which limits foraging of $U$. cordatus. Also, less-flooded mangrove forests tend to have a moresaline soil, which causes physiological stress on the crabs, slowing their growth and fattening rates (Sastry 1983; Christofoletti 2005; Schmidt 2006).

Diele et al. (2005) and others studying the sex ratio of $U$. cordatus found a predominance of males, particularly in areas where crab-catchers visit less often or those are less accessible. The mangrove areas in this study also are used by crab-catchers, but with no preference for specific mangrove forests (L. racemosa, A. schaueriana, and $R$. mangle), and therefore undergo similar exploitation pressure. Furthermore, in these mangrove forests, the crabcatchers do not prefer one gender only, as in north and northeast Brazil (Alves et al. 2005; Diele et al. 2005) where only males are sought because of their larger size.

The present study also showed that the sex ratio can vary as a function of tidal flooding level, which limits the diversity and nutritional value of the food in less-flooded L. racemosa forests, which do not receive leaves from adjacent forests. Although leaves of L. racemosa contain high concentrations of polyphenols (Lacerda et al. 1986; Christofoletti 2005), in more-flooded L. racemosa forests, these compounds significantly decrease with oxidation on soil (Godoy et al. 1997). Moreover, in more-flooded 
Fig. 6 Abundance of Ucides cordatus (males, black bars; females, white bars) by size classes $(C W$ carapace width in millimeters), in mangrove forests with a predominance of Laguncularia racemosa (Lh high mangrove; $L l$ low mangrove), Avicennia schaueriana (A), or Rhizophora mangle $(\mathrm{R})$, during breeding and non-breeding seasons

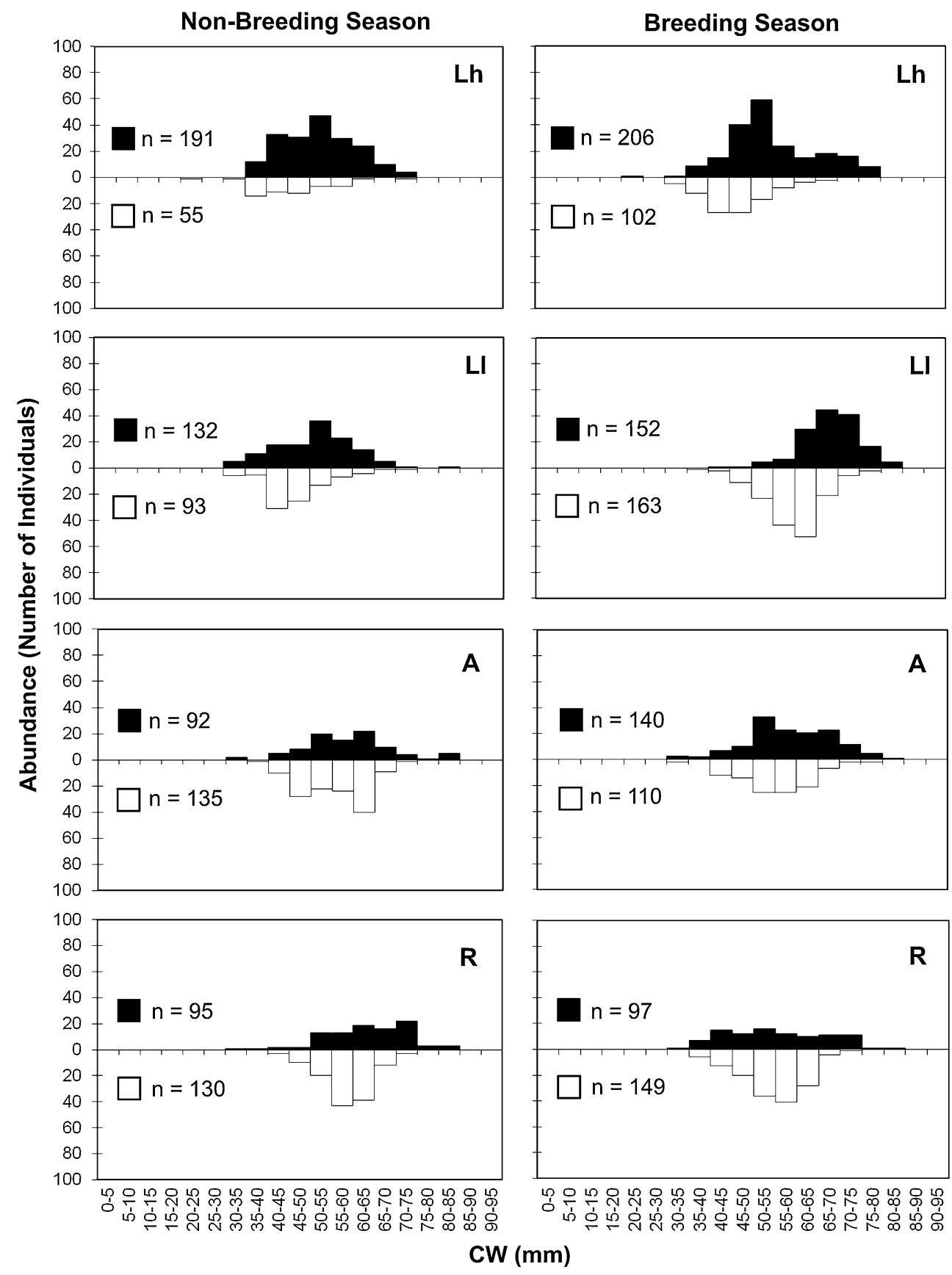

mangrove forests, the microbial decomposition process is more efficient, increasing the $\mathrm{C}: \mathrm{N}$ rates and reducing the astringency of the leaves (Alongi 1997; Christofoletti 2005). Hence, in less-flooded L. racemosa forests, the crabs are smaller and grow more slowly.

In $U$. cordatus, the predominance of females in moreflooded mangrove forests may result from the need for water during embryonic and larval development; for instance, Santos et al. (2009) observed that $70 \%$ of the females' burrows have their openings oriented toward the mangrove edge. This facilitates the access of ovigerous females to water, to release the larvae for dispersal by the tides (Diele 2000), explaining the migratory behavior previously reported for this species by Góes et al. (2000), and the greater abundance of females in more-flooded mangrove forests. According to Diele et al. (2005), this abundance of females is common at mangrove edges, favors the export of larvae, and improves their survival in the more-stable conditions outside the estuary (Diele and Simith 2006).

Our results provide insight into mangrove habitat partitioning by $U$. cordatus, revealing a significant relationship to environmental factors (tree-species composition and tidal flooding level) and biological period (breeding or 
non-breeding season). This contribution improves understanding of ecological processes in this species, particularly for the National Management Plan for sustainable harvesting of $U$. cordatus, proposed by the Brazilian Ministry of the Environment (Brasil 2011).

Acknowledgments We thank the Fundação de Amparo à Pesquisa do Estado de São Paulo (FAPESP) which granted a Scientific Initiation scholarship to ACW (Proc. \# 2006/07011-4) and financial support to MAAP (Proc. \# 1998/06055-0 and \# 2002/05614-2) to develop the Uçá Project (Phase I and II, respectively). We also thank the Instituto Brasileiro de Meio Ambiente e dos Recursos Naturais Renováveis (IBAMA) and the Instituto Chico Mendes de Conservação da Biodiversidade (ICM-Bio) for providing logistical support (Scientific Base at Iguape) during the project activities. We thank two anonymous reviewers of HMRE for suggestions and precious comments that greatly improved this manuscript, and finally to Dr. Janet W. Reid (JWR Associates) for editing the English text.

\section{References}

Alcântara-Filho P (1978) Contribuição ao estudo da biologia e ecologia do caranguejo-uçá, Ucides cordatus cordatus (Linnaeus, 1763) (Crustacea, Decapoda, Brachyura), no manguezal do Rio Ceará (Brasil). Arq Ciên Mar 18:1-41

Alongi DM (1997) Coastal ecosystem processes. CRC Press, London Alongi DM, Sasekumar A (1992) Benthic communities. In: Robertson AI, Alongi DM (eds) Tropical mangrove ecosystems. American Geophysical Union, Washington, pp 137-171

Alves DSM (2011) O papel das taxas de inundação na distribuição da vegetação e fauna em manguezais de um Estuário subtropical. Dissertation, Ciências Biológicas (Zoologia), Universidade Federal do Paraná

Alves RRN, Nishida AK (2004) Population structure of the mangrove crab Ucides cordatus (Crustacea: Decapoda: Brachyura) in the Estuary of the Mamanguape River, Northeast Brazil. Trop Oceanogr 32:23-37

Alves RRN, Nishida AK, Hernández MIM (2005) Environmental perception of gatherers of the crab "caranguejo-uçá" Ucides cordatus (Decapoda, Brachyura) affecting their collection attitudes. J Ethnobiol Ethnomed 1:1-10

Araújo MSLC, Calado TCS (2008) Bioecologia do Caranguejo-Uçá Ucides cordatus (Linnaeus) no Complexo Estuarino Lagunar Mundáu/Manguaba (CELMM), Alagoas, Brasil. Rev Gest Cost Integ 8:169-181

Brasil (2011) Proposta do Plano Nacional de Gestão para o Uso Sustentável do Caranguejo-Uçá, do Guaiamum e do Siri-Azul. Instituto Brasileiro do Meio Ambiente e dos Recursos Naturais Renováveis (IBAMA), Brasília

Campbell A (1992) Characteristics of the American lobster fishery of Grand Manan, New Brunswick, Canada. North Am J Fish Manag 12:139-150

Caravello HE, Cameron GN (1987) The effects of sexual selection on the foraging behavior of the Gulf coast fiddler crab, Uca panacea. Anim Behav 35:1864-1874

Castro ACL (1986) Aspectos bio-ecológicos do caranguejo-uçá, Ucides cordatus cordatus (Linnaeus, 1763), no estuário do Rio dos Cachorros e Estreito do Coqueiro, São Luís, Maranhão. Bol Lab Hidrobiol 7:7-26

Christofoletti RA (2005) Ecologia trófica do caranguejo-uçá, Ucides cordatus (Linnaeus, 1763) (Crustacea, Ocypodidae) e o fluxo de nutrientes em bosques de mangue, na região de Iguape (SP). $\mathrm{PhD}$ thesis, Faculdade de Ciências Agrárias e Veterinárias, Universidade Estadual Paulista

Conde JC, Alarcon S, Flores A, Diaz NDH (1995) Nitrogena and tannins in mangrove leaves might explain interpopulation variations in the crab Aratus pisonii. Acta Cient Venez 46:303-304

Cunha-Lignon M, Mahiques M, Schaeffer-Novelli Y, Rodrigues M, Klein D, Goya S, Menghini R, Tolentino C (2009) Analysis of mangrove forest succession, using cores: a case study in the Cananéia-Iguape Coastal System, São Paulo-Brazil. Braz J Oceanogr 57:1-13

deRivera CE (2003) Causes of a male-biased operational sex ratio in the fiddler crab Uca crenulata. J Ethol 21:137-144

Diele K (2000) Life history and population structure of the exploited mangrove crab Ucides cordatus cordatus (L.) (Decapoda: Brachyura) in the Caeté estuary, North Brazil. Center for Tropical Marine Ecology, Bremen

Diele K, Simith DJB (2006) Salinity tolerance of northern Brazilian mangrove crab larvae, Ucides cordatus (Ocypodidae): necessity for larval export? Estuar Coast Shelf Sci 68:600-608

Diele K, Simith DJB (2007) Effects of substrata and conspecific odour on the metamorphosis of mangrove crab megalopae, Ucides cordatus (Ocypodidae). J Exp Mar Biol Ecol 348:174182

Diele K, Koch V, Saint-Paul U (2005) Population structure, catch composition and CPUE of the artisanally harvested mangrove crab Ucides cordatus (Ocypodidae) in the Caeté estuary, North Brazil: indications for overfishing? Aquat Liv Resour 18:169178

Emmerson WD (1994) Seasonal breeding cycles and sex ratios of eight species of crabs from Mgazana, a mangrove estuary in Transkei, South Africa. J Crust Biol 14:568-578

Erickson AA, Bell SS, Dawes SJ (2004) Does mangrove leaf chemistry help explain crab herbivory patterns? Biotropica 36:333-343

Feller IC, Sitnik M (1996) Mangrove ecology: a manual for a field course. A field manual focused on the biocomplexity on mangrove ecosystems. Smithsonian Institution, Washington

Fleck DC, Layne JN (1990) Variation in tannin activity of acorns of seven species of central Florida oaks. J Chem Ecol 16:29252934

Frith DW, Brunenmeister S (1980) Ecological and population studies of fiddler crabs (Ocypodidae, genus Uca) on a mangrove shore at Phuket Island, western peninsular Thailand. Crustaceana 39: 157-184

Frusher SD, Giddins RL, Smith TJ III (1994) Distribution and abundance of grapsid crabs (Grapsidae) in a mangrove estuaryeffects of sediment characteristics, salinity tolerances and osmoregulatory ability. Estuar Coasts 17:647-654

Godoy SAP, Mayworm MAS, Lo VK, Salatino A, Schaeffer-Novelli Y (1997) Teores de ligninas, nitrogênio e taninos em folhas de espécies típicas de mangue. Rev Bras Bot 20:35-40

Góes P, Sampaio FDF, Carmo TMS, Tôso GC, Leal MS (2000) Comportamento e períodos reprodutivos do caranguejo do mangue Ucides cordatus. Simp Ecossist Bras 2:335-348

Góes P, Branco JO, Pinheiro MAA, Barbieri E, Costa D, Fernandes LL (2010) Bioecology of the Uçá-Crab, Ucides cordatus (Linnaeus, 1763), in Vitória Bay, Espírito Santo State, Brazil. Braz J Oceanogr 58:153-163

Guerrero-Ocampo CM (2002) Hábito alimentar em caranguejos grapsídeos de manguezais. $\mathrm{PhD}$ thesis, Universidade de São Paulo

Hai TN, Yakupitiyage A (2005) The effects of the decomposition of mangrove leaf litter on water quality, growth and survival of black tiger shrimp (Penaeus monodon Fabricius, 1798). Aquaculture 250:700-712 
Hattori GY (2006) Densidade populacional do Caranguejo-Uçá, Ucides cordatus (Linnaeus, 1763) (Crustacea: Brachyura: Ocypodidae) em Iguape, SP. PhD thesis, Faculdade de Ciências Agrárias e Veterinárias, Universidade Estadual Paulista

Hazlett BA, Bach CE, Thompson GA, MacLay CL (2005) Movement of male Heterozius rotundifrons (Crustacea: Decapoda: Brachyura) depends upon local sex ratio. New Zeal J Mar Fresh Res 39:157-163

Icely JD, Jones DA (1978) Factors affecting the distribution of the genus Uca (Crustacea: Ocypodidae) on an East African shore. Estuar Coast Shelf Sci 6:315-325

Iribarne OO, Martinez MM (1999) Predation on southwestern Atlantic fiddler crab (Uca uruguayensis) by migratory shorebirds (Pluvialis dominica, P. squatarola, Arenaria interpres, and Numenius phaeopus). Estuaries 22:47-54

Ivo CTC, Dias AF, Mota RI (1999) Estudo sobre a biologia do caranguejo-uçá, Ucides cordatus cordatus (Linnaeus, 1763), capturado no Delta do Rio Parnaíba, Estado do Piauí. Bol Téc Cient Cepene 7:53-84

Ivo CTC, Dias AF, Botelho ERO, Mota RI, Vasconcelos JA, Vasconcelos EMS (2000) Caracterização das populações de Caranguejo-Uçá, Ucides cordatus cordatus (Linnaeus, 1763), capturadas em estuários do nordeste do Brasil. Bol Téc Cient Cepene 8:7-43

Jaroensutasinee M, Jaroensutasinee K (2004) Morphology, density, and sex ratio of fiddler crabs from southern Thailand (Decapoda, Brachyura, Ocypodidae). Crustaceana 77:533-551

Johnson PTL (2003) Biased sex ratios in fiddler crabs (Brachyura, Ocypodidae): a review and evaluation of influence of sampling methods, size class and sex-specific mortality. Crustaceana 76: $559-580$

Jury SH, Kinnison MT, Howell WH, Watson WH (1994) The behavior of lobsters in response to reduced salinity. J Exp Mar Biol Ecol 180:23-37

Kandil FE, Grace MH, Seigler DS, Cheeseman JM (2004) Polyphenolics in Rhizophora mangle L. leaves and their changes during leaf development and senescence. Trees 18:518-528

Kelemec JA (1979) Effect of temperature on the emergence from burrows of the soldier crab Mictyris longicarpus (Latreille). Aust J Mar Fresh Res 30:463-468

Koch V, Wolff M, Diele K (2005) Comparative population dynamics of four fiddler crabs (Ocypodidae, genus Uca) from a North Brazilian mangrove ecosystem. Mar Ecol Prog Ser 291:177-188

Lacerda LD, José DV, Rezende CE, Francisco MCF, Wasserman JC, Martins JC (1986) Leaf chemical characteristics affecting herbivory in a New World mangrove forest. Biotropica 18: $350-355$

Linton SM, Greenaway P (2007) A review of feeding and nutrition of herbivorous land crabs: adaptations to low quality plant diets. J Comp Physiol B 177:269-286

Mendonça JT (2007) Gestão dos recursos pesqueiros do complexo estuarino-lagunar de Cananéia-Iguape-Ilha Comprida, litoral sul do Estado de São Paulo, Brasil. PhD thesis, Universidade Federal de São Carlos

Micheli F (1993) Effect of mangrove litter species and availability on survival, moulting and reproduction of the mangrove crab Sesarma messa. J Exp Mar Biol Ecol 171:149-163

Miyao SY, Nishihara L, Sarti CC (1986) Características físicas e químicas do sistema estuarino-lagunar de Cananéia-Iguape. Bol Inst Oceanogr 34:23-36

Mokhtari M, Savari A, Rezai H, Kochanian P, Bitaab A (2008) Population ecology of fiddler crab, Uca lactea annulipes (Decapoda: Ocypodidae) in Sirik mangrove estuary, Iran. Estuar Coast Shelf Sci 76:273-281

Monteiro BR, Filho PAC (2004) Estrutura populacional do Caranguejo-Uçá, Ucides cordatus (Linnaeus, 1763) (Crustacea,
Decapoda, Ocypodidae), no Estuário do Rio Paripe, Itamaracá, Pernambuco. Bol Téc Cient Cepene 12:99-111

Morrisey DJ, DeWitt TH, Roper DS, Williamson RB (1999) Variation in the depth and the morphology of burrows of the mud crab Helice crassa among different types of intertidal sediment in New Zealand. Mar Ecol Prog Ser 182:231-242

Mouton EC, Felder DL (1996) Burrow distributions and population estimates for the fiddler crabs Uca spinicarpa and Uca longisignalis in a Gulf of Mexico salt marsh. Estuaries 19:51-61

Nordhaus I, Wolff M (2007) Feeding ecology of the mangrove crab Ucides cordatus (Ocypodidae): food choice, food quality and assimilation efficiency. Mar Biol 151:1665-1681

Nordhaus I, Wolff M, Diele K (2006) Litter processing and population food intake of the mangrove crab Ucides cordatus in a high intertidal forest in northern Brazil. Estuar Coast Shelf Sci 67:239-250

Nordhaus I, Diele K, Wolff M (2009) Activity patterns, feeding and burrowing behaviour of the crab Ucides cordatus (Ucididae) in a high intertidal mangrove forest in North Brazil. J Exp Mar Biol Ecol 374:104-112

Nordi N, Nishida AK, Alves RRN (2009) Effectiveness of two gathering techniques for Ucides cordatus in Northeast Brazil: implications for the sustainability of mangrove ecosystems. Hum Ecol 37:121-127

Pedroche FF, West JA, Zuccarello GC, Sentíes AG, Karsten U (1995) Marine red algae of the mangroves in Southern Pacific México and Pacific Guatemala. Bot Mar 38:111-119

Pinheiro MAA, Fiscarelli AG (2001) Manual de apoio à fiscalização do caranguejo-uçá (Ucides cordatus). Instituto Brasileiro do Meio Ambiente e dos Recursos Naturais Renováveis (IBAMA), Itajaí

Pinheiro MAA, Fiscarelli AG (2009) Length-weight relationship of the carapace and condition factor of the mangrove crab Ucides cordatus (Linnaeus, 1763) (Crustacea, Brachyura, Ocypodidae). Braz Arch Biol Tech 52:397-408

Pinheiro MAA, Fiscarelli AG, Hattori GY (2005) Growth of the mangrove crab Ucides cordatus (Linnaeus, 1763) (Brachyura: Ocypodidae) at Iguape, SP, Brazil. J Crust Biol 25:293-301

Piou C, Berger U, Feller IC (2009) Spatial structure of a leafremoving crab population in a mangrove of North-Brazil. Wetl Ecol Manag 17:93-106

Post E (1936) Systematische und pflanzengeographische notizen zur Bostrychia-Caloglossa Assoziation. Rev Algol 9:1-84

R Development Core Team (2009) R: a language and environment for statistical computing. R Foundation for Statistical Computing, Vienna, Austria. ISBN 3-900051-07-0. http://www.R-project.org

Reese JC, Chan BG, Waiss AC (1982) Effects of cotton condensed tannin, maysin (Corn) and pinitol (soybeans) on Heliothis zea growth and development. J Chem Ecol 8:1429-1436

Reinsel KA (2004) Impact of fiddler crab foraging and tidal inundation on an intertidal sandflat: season-dependent effects in one tidal cycle. J Exp Mar Biol Ecol 313:1-17

Rhoades DF, Cates RG (1976) Toward a general theory of plant antiherbivore chemistry. Rec Adv Phytochem 10:168-213

Ribeiro PD, Iribarne OO, Daleo P (2005) The relative importance of substratum characteristics and recruitment in determining the spatial distribution of the fiddler crab Uca uruguayensis Nobili. J Exp Mar Biol Ecol 314:99-111

Rossi F, Chapman MG (2003) Influence of sediment on burrowing by the soldier crab Mictyris longicarpus Latreille. J Exp Mar Biol Ecol 289:181-195

Sandrini-Neto L, Lana PC (2011) Distribution patterns of the crab Ucides cordatus (Brachyura, Ucididae) at different spatial scales in subtropical mangroves of Paranaguá Bay (southern Brazil). Helgol Mar Res 66:167-174. doi:10.1007/s10152-0110258-z 
Santos CMH, Pinheiro MAA, Hattori GY (2009) Orientation and external morphology of burrows of the mangrove crab Ucides cordatus (Crustacea: Brachyura: Ucididae). J Mar Biol Ass UK 89:1117-1123

Sastry AN (1983) Ecological aspects of reproduction. In: Vernberg FJ, Vernberg B (eds) The biology of crustacea, vol 8. Academic Press, New York, pp 179-270

Schmidt AJ (2006) Estudo da dinâmica populacional do caranguejouçá, Ucides cordatus (Linnaeus, 1763) (Crustacea, Decapoda, Brachyura), e dos efeitos de uma mortalidade em massa desta espécie em manguezais do Sul da Bahia. PhD thesis, Universidade de São Paulo

Schories D, Barletta-Bergan A, Barletta M, Krumme U, Mehlig U, Rademaker V (2003) The keystone role of leaf-removing crabs in mangrove forests of North Brazil. Wetl Ecol Manag 11:243-255

Sokal RR, Rohlf FJ (1995) Biometry: the principles and practice of statistics in biological research. WH Freeman and Company, New York
Turra A, Gonçalves MAO, Denadai MR (2005) Spatial distribution of the ghost crab Ocypode quadrata in low-energy tide-dominated sandy beaches. J Nat Hist 39:2163-2177

Wenner AM (1972) Sex ratio as a function of size in marine Crustacea. Am Naturalist 106(949):321-350

Whitehouse RJS, Bassoulet P, Dyer KR, Mitchener HJ, Roberts W (2001) The influence of bedforms on flow and sediment transport over intertidal mudflats. Cont Shelf Res 20:1099-1124

Wilson K, Hardy ICW (2002) Statistical analysis of sex ratio: an introduction. In: Hardy ICW (ed) Sex ratios: concepts and research methods. Cambridge University Press, Cambridge, pp 48-92

Wunderlich AC, Pinheiro MAA, Rodrigues AMT (2008) Biologia do caranguejo-uçá, Ucides cordatus (Crustacea: Decapoda: Brachyura), na Baía da Babitonga, Santa Catarina, Brasil. Rev Bras Zool 25:188-198

Zar JH (2010) Biostatistical analysis. Prentice-Hall, Upper Saddle River 